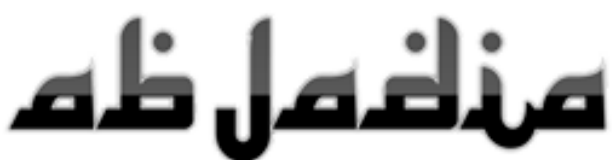

International Journal of Education

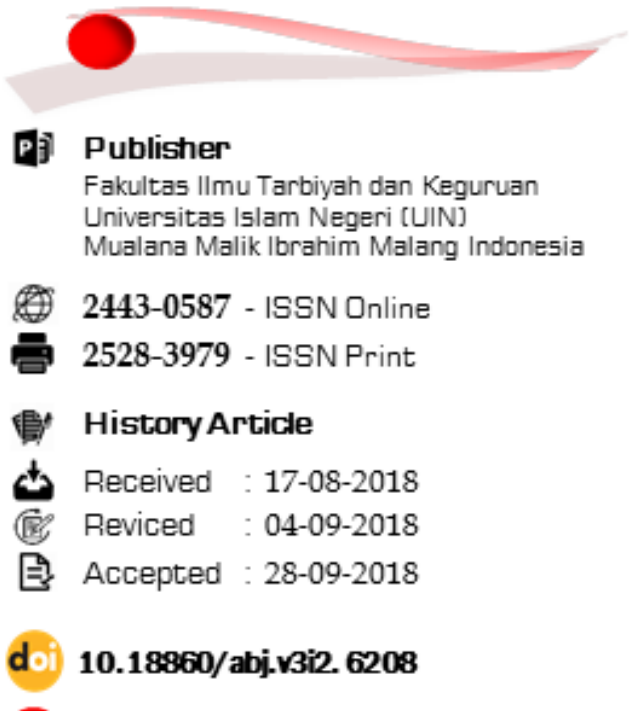

http://ejournal.uin-malang.ac.id/index.php/ abjadia/article/view/6208

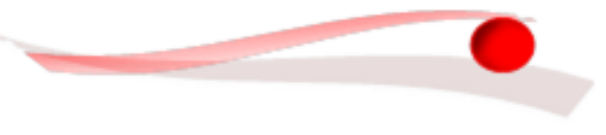

\footnotetext{
Q Albar Adetary Hasibuan

I. Indonesia

(3) Universitas Brawijaya
}
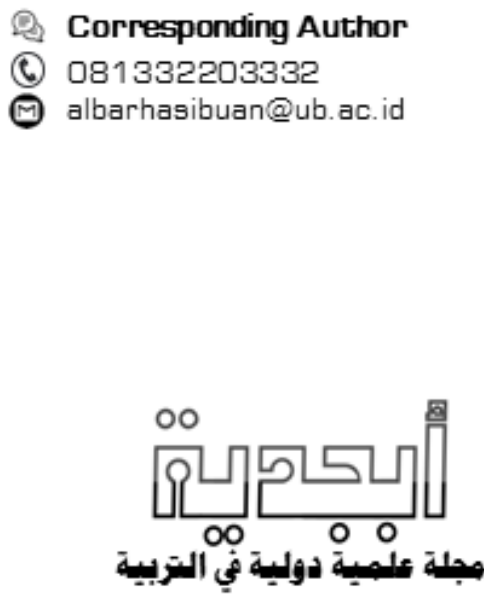

Albar Adetary Hasibuan

Indonesia

\section{COMPUTER MEDIATED \\ COMMUNICATION, THE WAY FOR DEVELOPING STUDENTS' ARABIC WRITING ABILITY}

\section{留" Abstract}

Computer Mediated Communication, better known as $\mathrm{CMC}$, can be used as a tool in improving students' Arabic writing skills. CMC is used because computers and networks are familiar to students now. CMC can also make learning to write Arabic more creative and innovative. The purpose of writing this article is to provide information about computer-mediated communication (CMC) and also how to apply $\mathrm{CMC}$ to learning to write Arabic, to improve student writing skills.

@. Computer Mediated Communication, Arabic Language, Writing Skills

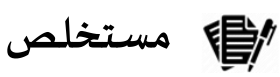

يمكن استخدام التواصل عبر الكمبيوتر ، المعروف باسم CMC ، كأداة لتحسين مهارات الطلاب في الكتابة باللغة العربية. يتم

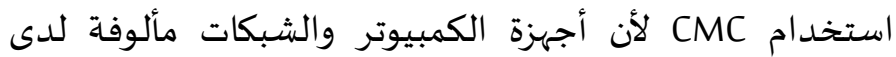
الطلاب الآن. يمكن أن تجعل CMC تعلم الكتابة العربية أكثر

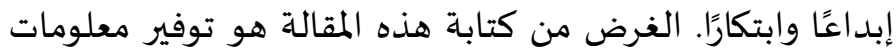
حول التواصل عبر الكمبيوتر (CMC) وأيضًا كيفية تطبيق CMC على تعلم الكتابة باللغة العربية ، لتحسين مهارات كتابة الطلاب.

$$
\text { التواصل عبر الكمبيوتر ، اللغة العربية ، مهارات الكتابة }
$$

Citation: Hasibuan, Albar Adetary. (2018). Computer Mediated Communication, The Way for Developing Students' Arabic Writing Ability. Abjadia: International Journal of Education, 3(2), 91-99. 


\section{(C) INTRODUCTION}

Writing is an important communication skill in today's information society, but difficult to obtain. Especially when it comes to writing a second language, the level of difficulty will increase. Language differences cause differences in structure, language style, ways of expressing thoughts, and other cultural factors that influence the writing of foreign language students. For example, in terms of the context of the sentence, the word ruzzun in Arabic does not necessarily mean nasi, it can also mean padi according to the context of the sentence that accompanies the Arabic word.

Writing is not like speaking, which is an activity to deliver messages or information to listeners at one time, whereas a writer cannot communicate with the reader directly. This becomes difficult because the author does not know whether the reader of his writing understands the purpose he delivered or not. Another difficulty is in terms of language, there is a difference between writing a diary with writing scientific papers and so on. No less difficult for a writer is to put ideas on paper in writing. These difficulties often prevent a person from developing his writing skills (Mohamed \& Zouaoui, 2014).

In this era of information and communication, students tend to be unproductive. They prefer to copy the text they found on the internet and make it as a result of their paper, so that plagiarism is inevitable. Students feel that their less of knowledge about vocabulary, grammar, the usability of language signs, the preparation of clauses and the difficulty of finding writing learning methods that are in accordance with their conditions does not achieve the goal of writing learning (Trimantara \& Pd, 2005). No less important is the limitation even the absence of innovative writing learning media that can attract their interest in developing writing.

This condition is also experienced by students learning a second language, in this case Arabic. One class of language that is excessively student causes them not to get enough opportunity to interact using Arabic to express their intentions and thoughts. Usually, intelligent students may present accurate writing while weak students feel hesitant, not trying to write because of the lack of knowledge needed to carry out the writing assignment. Undoubtedly, such an environment is a demand for lecturers to be more creative and innovative in presenting writing media for all their students (Mohammad, 2018).

The more rapid development of the times, the media to improve writing skills must be more sophisticated. Students are expected to overcome the difficulties they face in writing Arabic skills. So that later not only write as a form of cognitive results they get during the learning process, even with advanced technology, their writing can 
develop into scientific works that can develop new things in the field of second language learning especially Arabic.

So the description above, the author provides a solution to the difficulties experienced by students in the process of improving their writing skills. The solution given is to use computer mediated communication, where people use computer keyboards in writing to communicate rather than face to face which might cause communication delays due to shame. Besides that writing using a computer device compared to manual writing on paper also provides its own advantages, which is the existence of grammar checking tools, thus minimizing writing errors.

Computers are used to improve students' Arabic writing skills, because computers and networks are already familiar with students in today's technological age. The widespread use of computers and the internet has turned CMC into an important communication medium that has been used freely and effectively for various purposes including interpersonal communication, information transfer, pedagogical purposes, etc (Shin, t.t.). The integration of technology into the educational environment is expected to have a many positive effects on learners of Arabic and can increase their motivation for Arabic.

Many previous studies on CMC applied in language learning such as Zheng and Warschauer, they discussed the importance of digital technology that has transformed into the form, genre and purpose of writing even inside the classroom and outside it. Their writing focuses on CMC which has an important role for researchers, educators, and instructors in the current technological era (Zheng \& Warschauer, 2017). Besides that Cummings conducted CMC experiments in this online course for EFL writers, there were positive changes in attitude, motivation, and the relationship between instructor and student. As a result CMC can relieve some stress and / or give teachers a different perspective on their students (Cummings, t.t.).

This is interesting for writers because the application of CMC does not yet appear in Arabic writing learning. So the authors set the purpose of writing this article, there are to provide views on computer mediated communication and its application as a way to improve students' Arabic writing skills. In addition, this study is expected to contribute to other studies relating to Arabic writing skills, by investigating whether new technologies can broaden the focus and potential benefits of an Arabic learner.

\section{QQ] RESEARCH METHOD}

To conduct this study, the authors will follow the descriptive method. Data will be collected from secondary sources, i.e., reference books, journals, the Internet and the previous studies. 


\section{FINDINGS}

\section{Computer Mediated Communication (CMC)}

$\mathrm{CMC}$ is one of the theories included in the science of communication where communication is done using computer media. The term CMC was first introduced by Hiltz and Turoff (1978) when they experimented with the use of computers and telecommunications technology to discuss between people who operate computers in different places (Hosseini, 2015). The more recent definition of CMC was put forward by Barnes (2002), he defined CMC as a technology that paved the way for humans to interact and share the information through interconnected computer networks including small or large group discussions, e-mail, newsgroups, and live chat (Hosseini, 2015).

There are several obstacles found in CMC. This is because between humans who are involved in a topic of conversation are not directly face to face. These constraints can be physical, language and social variables (Baron, t.t.). Suppose the consideration that $\mathrm{CMC}$ has developed into a means that can compensate for the physical absence of the interlocutor (nonlinguistics context) as an example of how someone can tell others that he is sleepy during a conversation, because the other person cannot see his friend's physical condition as often yawn and red eyes. Textbased CMC loses nonverbal cues such as faces expression, gesture or tone of conversation (Daft and Lengel 1984; Kiesler 1986; Rice and Love 1987; Culnan and Marcus 1987) (Xu \& Yi, t.t.).

Other obstacles can be found in terms of language and social. For example, the consideration that CMC can reduce or increase someone's grammar level, is there a difference between oral grammar and writing. An example is the choice of pronouns to refer to the other person, for example anta in Arabic for peers or antum for older people. This raises social variables: Does computer mediated communication reduce or increase social distance levels? Does it affect the extent to which the other person participates in the conversation, or how honest are they in expressing their opinions?

\section{CMC as a Learning Tool}

Rapid technological change is happening as it is now forcing teachers to find more innovative and creative teaching methods. The teachers have to design methods, tools, techniques for preparing students to be better in adapting and dealing with new technologies that give students the opportunity to be examined and work with the new technologies. One tool that can be used by instructors to explore their students' abilities is CMC. CMC is fairly new in the field of education. CMC evolves along with the expansion of the internet network as it is today. Terms such as email, telecommuting, 
online databases, electronic bulletins, edmodo, group chat, are used as tools for learning.

The example of the people who researched CMC as a tool that can be used in the teaching field are Donna R. Everett and Terence C. Ahern. Their research is to observe the effect of computer-mediated communication (CMC) application and compatible groupware as teaching tools by considering the effects that occur on students, class structure, and interpersonal interactions. The results of the experiments they conducted showed that the use of CMC can have the positive effects on students and interpersonal interactions, but the practice of this technology have to be integrated correctly into the teaching purposes (Everett \& Ahern, 1994).

The benefit of CMC is that learners become more independent and they have the way to contact the teachers outside the class. CMC also allows people to communicate by transferring written messages in the form of short notes or written data files. Learners can also interact anytime and how long they want. Learning is open and flexible, can be formed as a whole class or space for small groups to work together (McComb, 1994).

\section{The Rules of CMC}

$\mathrm{CMC}$ is a type of virtual communication where users are not directly face to face, but use computers in the interaction process, therefore there must be control behavior among group members. CMC must have rules that can be applied and followed by all group members. According to Walther, Bunz \& Bazarova there are 6 rules of CMC (Walther, Bunz, \& Bazarova, 2005).

\section{Start immediately}

Traditionally, face-to-face discussions of a group tend to delay the completion of the work. Such a delay might occur in CMC and this is more damaging to the deadline for resolving results. Thus, the CMC group must start early to avoid running out of time to move to the next topic. Keep in mind that successful groups start their work quickly.

\section{Frequent communication}

Communicating as often as possible can indicate group development. The value of frequent communication is also identified as critical behavior and can avoid a pile of activities towards the deadline for group work time.

\section{Tasks must be organized and carry out substantive work simultaneously}

This rule is based on the use of CMC which is temporal which has a time limit for work assignments. So that traditional settings about organizing, defining and allocating tasks are not efficient in CMC. This is because organizing uses a lot of time so 
there is not enough time for writing content. For the most efficient use of time in virtual groups it is better to start writing content than to wait until every aspect has been organized.

\section{Open acknowledgment that the message has been read}

In some types of CMC it is difficult to say whether other people have read posting someone or not, this might be due to a sender's error, a system error or recipient's behavior that doesn't check. So from that it is necessary to openness to the reception of the message in the form of explicit thanks that the message has been read.

\section{Explanation explicitly about thoughts and what will be done}

CMC must be able to translate into explicit verbal behavior that has traditionally been done nonverbally, approval nods or shaking heads a sign of disagreement to know the response in communication. Because when someone does not explicitly state agreement or disapproval in the virtual group, other members do not know, but may mistakenly assume, that the group agrees. This can cause conflicts and misdirection about the tasks received.

\section{Set a deadline and obey it}

It is important for a group to complete tasks in a timely manner. In this case, there needs to be trust between group members and respect for the agreements that have been established together.

In addition to the technical rules above, there are many things that need to be considered among fellow group members. There should be no content that is discriminatory, profane, hateful and racial messages, there should be no content messages that intentionally offend other members, no advertisements, spamming, or solicitation, do not duplicate the account so that it confuses other members, and more importantly group members must read and obey special rules in each group (Pratiwi \& Si, 2014).

\section{jị DISCUSSIONS}

\section{How to Use CMC in Arabic Writing Learning}

The first step that must be done by lecturers and students in using CMC is to determine the type of CMC. They can use synchronous communication such as instant messaging, Internet Relay Chat (IRC), asynchronous communication such as e-mail, discussion boards, bulletin boards (Xu \& Yi, t.t.). There are also other applications that can be used to communicate in groups such as Edmodo, Whatsapp groups, Instagram, Facebook groups and others. 
As an illustration of the use of CMC in learning Arabic writing, the writer describes the steps to use CMC to improve the writing skills of Arabic students. Lecturers can divide the class into several discussion groups in order to provide maximum feed back. All posts, directions, questions, and information are written in Arabic. In detail, the steps are as follows :

1. The lecturer posts a notification of the topic in the group, for example the topic chosen is about Traveling (الرحلة).

2. Students read and post their own messages about experiences, questions, and information related to topics on bulletin boards.

3. Lecturers provide shared resources and respond to questions or issue directives and guidelines such as project assignments and formats, bibliography, and others

4. Students and lecturers have access to other online resources such as experts in topic areas or Internet information sources.

The expected results after the discussion in the group forum on the topic determined by the lecturers, namely students submit their group assignments in the form of writing the results of online discussions to lecturers, then the lecturers comment on them and return them. The students then revised their writing until the lecturers agreed to move to the next topic. The group sends weekly reports about their progress in writing to the lecturer in person to get their comments and guidance.

Besides being able to discuss topics related to Arabic lessons in class, they can also comment on each other about Arabic films that are watched both together in class and that have been sent online for each student to watch.

1. Students post on comments, observations, and bulletin boards about the Arabic films they have watched. Questions can be about the new vocabulary they are listening from films, the film's storyline, even about the actors or actress.

2. Students read and react to other people's comments in the group

3. The lecturer inserts questions, interpretations, synthesis, praise, validation, etc. in response to student discussions.

4. The final results are written on reviews of Arabic-language films obtained from the results of student discussions on the films they watched.

CMC answers practical needs in learning to write Arabic. This is because CMC allows a group of students to maintain a communication relationship with the lecturer intensely. CMC allows students to keep discussing even though class time has ended. But, besides this practical benefit, CMC helps produce a learning environment that 
transcends time and space, where students and teachers have a balance of communication. CMC forms an efficient environment, which can give rise to a more relaxed and conducive atmosphere because communication is not one-way from teacher to student within the limits of class and study hours but communication that is formed is two-way communication between lecturers and students

\section{CONCLUSION}

Communication that is mediated by computers or better known as CMC can be used as an Arabic learning tool specifically to improve student skills in writing. Although CMC based on text loses nonverbal cues such as facial expressions, gestures or conversational tones, it can be overcome by following established rules. Students feel comfortable discussing without having to meet face to face, and can write the results of discussion conclusions as a report the assignment given by the lecturer.

In accordance with the results of the discussion above, several suggestions were given to lecturers of Arabic to be positive towards computer-mediated teaching because it affects the practice in the classroom, so it is necessary for lecturers to have a positive attitude so that they can be successfully used. Although Arabic language lecturers are not familiar with computer-mediated language teaching classes in the education system, that does not mean that one must override it and follow traditional methods of language teaching. Even lecturers are encouraged to adopt this tool in their classrooms to create creative and innovative Arabic language learning techniques. The lecturers must be given the opportunity to educate themselves in areas related to CMC tools and apply the teaching practices of these tools.

\section{BIBLIOGRAPHY}

Baron, N. S. (t.t.). Computer Mediated Communication as a Force in Language Change, 24.

Cummings, M. C. (t.t.). "Because We Are Shy and Fear Mistaking": Computer Mediated Communication with EFL Writers, 26.

Everett, D. R., \& Ahern, T. C. (1994). Computer-Mediated Communication as a Teaching

Tool: A Case Study. Journal of Research on Computing in Education, 26(3), 336-357.

https://doi.org/10.1080/08886504.1994.10782095

Hosseini, S. B. (2015). COMPUTER-MEDIATED COMMUNICATION: PEDAGOGICAL AND LANGUAGE LEARNING IMPLICATIONS, 6(1), 14. 
McComb, M. (1994). Benefits of computer-mediated communication in college courses. Communication Education, 43:2, 159-170.

https://doi.org/10.1080/03634529409378973

Mohamed, M., \& Zouaoui, M. (2014). EFL Writing Hindrances and Challenges: The case of Second Year Students of English at Djillali Liabes. Journal of Educational and Social Research. https:/ / doi.org/10.5901/jesr.2014.v4n3p149

Mohammad, H. M. F. (2018). EFL Learners' Attitudes towards Cooperative Learning in the Writing Skill. International Journal of Language and Linguistics, Vol. 5, No. 4. https:// doi.org/10.30845/ijll.v5n4p11

Pratiwi, F. D., \& Si, M. (2014). COMPUTER MEDIATED COMMUNICATION (CMC) DALAM PERSPEKTIF KOMUNIKASI LINTAS BUDAYA (Tinjauan Pada Soompi Discussion Forum Empress Ki TaNyang Shipper), 7(1), 16.

Shin, D.-S. (t.t.). ESL Students' Computer-Mediated Communication Practices: Context Configuration. Language Learning, 20.

Trimantara, P., \& Pd, S. (2005). Metode Sugesti-Imajinasi dalam Pembelajaran Menulis dengan Media Lagu, 14.

Walther, J. B., Bunz, U., \& Bazarova, N. N. (2005). The Rules of Virtual Groups. Th Hawaii International Conference on System Sciences, 10.

Xu, L., \& Yi, C. (t.t.). 81. Emotional Expression Online: the Impact of Task, Relationship and Personality Perception on Emoticon Usage in Instant Messenger, 15.

Zheng, B., \& Warschauer, M. (2017). Epilogue: Second language writing in the age of computer-mediated communication. Journal of Second Language Writing, 36, 61-67. https://doi.org/10.1016/j.jslw.2017.05.014

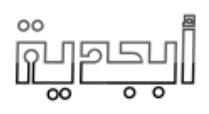

